\title{
APLIKASI MUTAN BERFLUORESENS UNTUK MEMPELAJARI KETAHANAN HIDUP, KOLONISASI DAN PENETRASI ISOLAT Cronobacter sakazakii SELAMA PENGERINGAN JAGUNG
}

\author{
[Use of GFP Mutant to Study the Survival, Colonization and Penetration of Cronobacter sakazakii Isolates \\ During Maize Drying]
}

\author{
Siti Nurjanah ${ }^{1,2)^{*}}$, Maggy T. Suhartono1), Ratih Dewanti-Hariyadi1,2) dan Sri Estuningsih ${ }^{3)}$ \\ 1) Departemen IImu dan Teknologi Pangan, Fakultas Teknologi Pertanian, Institut Pertanian Bogor, Bogor \\ 2) SEAFAST Center, Institut Pertanian Bogor, Bogor \\ 3) Departemen Klinik Reproduksi dan Patologi, Fakultas Kedokteran Hewan, Institut Pertanian Bogor, Bogor
}

Diterima 22 Oktober 2013 / Disetujui 05 Desember 2013

\begin{abstract}
Cronobacter sakazakii is a Gram-negative emerging pathogen regarded as causative agent of meningitis and necrotizing enterocolitis in certain groups of infants. In the previous research, thirty-two local isolates of $C$. sakazakii were obtained from various dried food products such as from corn starch, suggesting that they are able to survive drying. Some of the isolates were toxic. Green Fluorescent Protein (GFP) have been inserted to C. sakazakii and used as a marker for selective enumeration due to the ability of this protein to fluoresce under UV and to tolerate in ampicillin containing media. The objective of this study was to evaluate the survival, colonization and penetration of two isolates of $C$. sakazakii from dried food product during maize drying. The maize was challenged with mutants at a concentration of $10^{5}-10^{6} \mathrm{CFU} / \mathrm{g}$ before drying. Maize drying was performed at temperature of 40,45 and $50^{\circ} \mathrm{C}$ for 4,6 and 8 days until the moisture content reached $14 \%$. The totals of resistant drying mutants were counted every day onto ampicillin containing media by observing under UV light. The survival rate of C. sakazakii during drying was determined by the slope of linier regression from C. sakazakii survival curve. Isolates of FWHd16, the toxic strain of C. sakazakii, were more resistant to heat treatments in comparison to isolates of YRt2a, or the non toxic strain of $\mathrm{C}$. sakazakii. Following fluorescence and scanning electron microscope observation, it is concluded that both isolates were colonizing on maize surface. These mutants were able to penetrate to the inner side of the grain by entering injured surface or pores at the tip cap of maize.
\end{abstract}

Keywords: Cronobacter sakazakii, GFPuv, maize, mutant, survival

\begin{abstract}
ABSTRAK
Cronobacter sakazakii merupakan bakteri Gram negatif yang dapat menyebabkan meningitis dan necrotizing enterocolitis pada kelompok bayi tertentu. Pada penelitian sebelumnya telah diisolasi tiga puluh dua isolat $C$. sakazakii dari beberapa produk pangan kering termasuk maizena, yang mengindikasikan ketahanan bakteri tersebut terhadap proses pengeringan. Sebagian isolat telah dievaluasi memiliki aktivitas toksik. Green Fluorescent Protein (GFP) telah berhasil disisipkan pada C. sakazakii dan digunakan sebagai penanda untuk perhitungan koloni secara selektif karena kemampuannya berfluoresens di bawah sinar UV dan tumbuh di media mengandung ampisilin. Penelitian ini bertujuan untuk mengevaluasi ketahanan hidup, kemampuan kolonisasi dan penetrasi dua isolat $C$. sakazakii selama proses pengeringan jagung menggunakan mutan berlabel GFP. Jagung diinokulasi dengan mutan pada konsentrasi $10^{5}-10^{6} \mathrm{CFU} / \mathrm{g}$ sebelum proses pengeringan. Pengeringan jagung dilakukan pada suhu 40,45 dan $50^{\circ} \mathrm{C}$ selama 4,6 dan 8 hari sampai kadar air mencapai $\leq 14 \%$. Jumlah koloni yang tahan terhadap pengeringan dihitung setiap hari pada media yang mengandung ampisilin melalui pengamatan di bawah sinar UV. Laju penurunan $C$. sakazakii selama pengeringan ditunjukkan oleh slope regresi linier dari kurva ketahanan hidup. Isolat toksik FWHd16 lebih tahan pada ke-3 suhu pengeringan dibandingkan dengan isolat nontoksik YRt2a. Pengamatan dengan mikroskop fluoresens dan SEM menunjukkan bahwa kedua isolat mampu berkolonisasi di permukaan jagung. Kedua isolat dapat berpenetrasi ke dalam jagung melalui bagian yang luka atau melalui rongga-rongga di bagian tip cap.
\end{abstract}

Kata kunci: Cronobacter sakazakii, GFPuv, jagung, ketahanan hidup, mutan

\section{PENDAHULUAN}

Cronobacter sakazakii merupakan salah satu dari 6 spesies dalam Genus Cronobacter spp. (sebelumnya dikenal sebagai Enterobacter sakazakii) (Iversen et al. 2008). Cronobacter spp. telah diisolasi dari berbagai sumber pangan, sumber klinis, dan

*Penulis Korespondensi:

Email: siti.nrjh@gmail.com; Telp. 08128263685 lingkungan. Bakteri ini telah dilaporkan dapat menyebabkan necrotizing enterocoliticus (NEC) (Emami dan Mittal, 2012), meningitis dan bacterimia (Bowen dan Braden, 2006) pada bayi kelompok tertentu. Di Indonesia, C. sakazakii telah diisolasi oleh Estuningsih et al. (2006), Meutia et al. (2008), Gitapratiwi et al. (2012) dan Hamdani (2012). Semua isolat tersebut diperoleh dari produk pangan kering, yaitu susu formula, makanan pendamping ASI, maizena, tepung terigu, tapioka, coklat bubuk, gula halus serta rempah kering. 
Sejak tahun 2009, di Indonesia mulai diberlakukan SNI 7388-2009 yang mengatur batas maksimum cemaran mikroba dalam pangan yang mengatur bahwa cemaran Cronobacter spp. pada susu formula harus negatif (BSN, 2009). Agar persyaratan tersebut dapat dipenuhi oleh industri, diperlukan informasi mengenai faktor-faktor yang diduga berkontribusi pada adanya kontaminasi bakteri ini pada susu formula. Menurut CAC (2008), Cronobacter spp. dapat masuk ke dalam susu formula melalui kontaminasi dari lingkungan proses pada tahapan tertentu selama pengeringan, kontaminasi susu formula setelah kemasan dibuka, dan kontaminasi selama atau setelah proses rekonstitusi. FAO-WHO (2004) menyebutkan bahwa faktor yang berisiko menyebabkan Cronobacter spp. mencemari produk susu bubuk dapat berasal dari ingridien yang ditambahkan pada tahap pencampuran kering tanpa adanya tahapan pemanasan lanjutan.

Beberapa penelitian terakhir mendukung bahwa kontaminasi dapat berasal dari ingridien yang digunakan dalam pembuatan susu formula dan makanan pendamping ASI. Dewanti-Hariyadi et al. (2010) mengisolasi C. sakazakii dari maizena, Fiegen (2010) di Jerman juga mengisolasi 10 isolat $C$. sakazakii dari beberapa ingridien susu (maizena, lesitin kedelai, pati kentang, pati gandum, dan pati beras), 5 isolat diantaranya berasal dari maizena. Hasil survey FAO-WHO (2004) menunjukkan bahwa cemaran $C$. sakazakii dalam ingridien susu bubuk paling banyak berasal dari pati-patian. Hal ini memperkuat dugaan bahwa kontaminasi bakteri pada susu bubuk dapat berasal dari ingridien. Permasalahan yang muncul selanjutnya adalah bagaimana bakteri ini dapat berada dan bertahan dalam maizena. Sebagai tahapan awal, dalam penelitian ini dilakukan penelusuran $C$. sakazakii pada bahan baku maizena yaitu jagung, melalui kajian ketahanan hidup terhadap proses pengeringan, kemampuan kolonisasi dan penetrasi bakteri ini selama pengeringan jagung.

Saat ini jagung digunakan sebagai salah satu bahan dasar pembuatan produk pangan kering. Beberapa produk pangan kering berbasis jagung yang dilaporkan terkontaminasi Cronobacter spp. selain maizena adalah yaitu gritz jagung (Iversen dan Forsythe, 2004a) dan tepung jagung (Restaino et al. 2006). Untuk mempelajari perilaku bakteri pada bahan pangan (dalam hal ini jagung) dengan menggunakan metode konvensional ditemukan kesulitan dalam membedakan bakteri target dengan mikroorganisme lainnya, karena jagung mengandung mikroorganisme dengan jumlah dan jenis yang beragam. Mikroba yang dapat tumbuh pada jagung sangat beragam baik dari kelompok kapang (Aspergillus, Fusarium, Penicillium, Rhizophus), kamir (Kodamaea dan Candida) dan bakteri (Pediococcus dan Lactobacillus) (Rahmawati et al. 2013).

Teknik pelabelan menjadi salah satu alternatif penelusuran perilaku bakteri ini tanpa menekan pertumbuhan ataupun membunuh mikroba lainnya. Penelitian ini menggunakan pelabelan dengan plasmid yang mengandung Green Fluorescent Protein (pGFPuv) yang disisipkan ke dalam C. sakazakii. GFP merupakan protein Aequorin yang berasal dari ubur-ubur (Aequorea victoria) yang dapat berfluoresens (Nifosi et al. 2005). Protein ini telah diisolasi pertama kali oleh Shimomura tahun 1961 (Shimomura, 2005), kemudian dikembangkan oleh beberapa peneliti, disisipkan pada plasmid dan dapat diekspresikan baik pada inang eukariot maupun prokariot (Ehrenberg, 2008). pGFPuv merupakan variasi dari pGFP yang mempunyai intensitas fluoresens 45 kali lipat melalui proses DNA shuffling (Crameri et al. 1996). C. sakazakii terlabel menunjukkan koloni spesifik berwarna hijau fluoresens dan tumbuh pada media mengandung ampisilin. Karakteristik lain dari pGFPuv ini adalah kestabilan pada kondisi lingkungan yang asam, $\mathrm{NaCl}$ tinggi dan suhu rendah ataupun tinggi (Vialette, 2004), dan mempunyai stabilitas termal yang tinggi pada suhu kurang dari $100^{\circ} \mathrm{C}$ (Penna et al. 2004), sehingga pGFPuv dapat diaplikasikan pada perlakuan yang menggunakan panas.

Karena bakteri ini ditemukan pada beberapa produk pangan kering berbasis jagung, maka diduga bakteri ini dapat bertahan pada proses pengeringan jagung. Ketahanan Cronobacter spp. terhadap panas tergantung pada strain, suhu, dan kandungan air (Arroyo et al. 2009). Ketahanan terhadap pengeringan ini diduga karena kemampuan Cronobacter spp. berkolonisasi pada permukaan bahan pangan dan juga masuk ke dalam bahan pangan yang dapat melindunginya dari panas. Penelitian ini bertujuan untuk mempelajari ketahanan hidup dua isolat $C$. sakazakii, kemampuan kolonisasi dan penetrasi pada proses pengeringan jagung menggunakan mutan terlabel Green Fluorescent Protein. Dua isolat C. sakazakii yang digunakan mempunyai toksisitas yang berbeda, isolat YRt2a bersifat nontoksik, sedangkan isolat FWHd16 bersifat toksik. Hasil penelitian ini diharapkan mampu menjawab faktor-faktor yang berkontribusi menyebabkan adanya cemaran $C$. sakazakii pada produk kering berbasis jagung.

\section{BAHAN DAN METODE}

\section{Bahan}

Bahan yang digunakan dalam penelitian ini adalah 2 isolat mutan Cronobacter sakazakii FWH d16 dan YRt2a (Nurjanah et al. 2012) yang disisipi plasmid pGFPuv (Clontech USA) (Gambar 1) (Tabel 1). Druggan-Forsythe-Iversen (DFI, DIFCO). Bahan segar yang digunakan adalah jagung varietas Pioneer 12 (PT. Pioneer Hibrida Indonesia).

Tabel 1. Karakteristik isolat dan plasmid yang digunakan

\begin{tabular}{|c|c|c|c|}
\hline Kode Isolat'1//Plasmid & & Aktivitas & \\
\hline $\begin{array}{c}\text { GenBank Accession } \\
\text { Number }\end{array}$ & Sumber & $\begin{array}{l}\text { Sitotoksik } \\
\text { Toksin'2) }\end{array}$ & Referensi \\
\hline YRt2a/ JF800182 & Susu formula & Negatif & $\begin{array}{c}\text { Meutia et al. } \\
2008\end{array}$ \\
\hline FWHd16/ JX535018 & Lada bubuk & Positif & Hamdani 2012 \\
\hline Plasmid GFPuv & $\begin{array}{l}\text { Clontech, } \\
\text { USA }\end{array}$ & & \\
\hline
\end{tabular}

\section{Persiapan mutan C. sakazakii sebagai inokulum}

Isolat yang dinokulasikan (inokulum) ke jagung adalah isolat mutan C. sakazakii YRt2a dan FWHd16 dari stok beku yang diinkubasi dalam media Brain Heart Infusion (BHI, DIFCO) pada suhu $37^{\circ} \mathrm{C}$ selama 24 jam. Pembuatan mutan telah dilakukan sebelumnya dengan cara pembuatan sel kompeten dan transformasi. Pembuatan sel kompeten dilakukan dengan cara pemisahan sel bakteri dari medium pertumbuhannya 
dengan sentrifugasi $\left(2600 \times \mathrm{g}, 4^{\circ} \mathrm{C}, 10\right.$ menit). Sel bakteri yang telah terpisah disuspensikan dalam $10 \mathrm{~mL}$ larutan TF $(10 \mathrm{mM}$ Tris. $\mathrm{HCl}, 100 \mathrm{mM} \mathrm{CaCl}$ ), didiamkan di dalam es selama 30 menit, kemudian disentrifugasi kembali pada kondisi yang sama. Pelet disuspensikan dalam $0.3 \mathrm{~mL}$ larutan TF. Transformasi sel bakteri dilakukan dengan mencampurkan $40 \mu \mathrm{L}$ sel kompeten dengan $2 \mu \mathrm{L}$ DNA pGFPuv dalam tabung Eppendorf, didiamkan di dalam es selama 30 menit dan diberikan kejut panas pada suhu $42^{\circ} \mathrm{C}$ selama 60 detik. Setelah itu ditambahkan medium recovery SOC sebanyak $400 \mu \mathrm{L}$, diinkubasi selama 1 jam, $37^{\circ} \mathrm{C}$, kemudian disentrifugasi $(2600 \mathrm{x}$ $\mathrm{g}, 4^{\circ} \mathrm{C}, 10$ menit). Supernatan dibuang, dan pelet diresuspensi dengan Buffer Water Phosphate (BPW, OXOID) sebanyak $100 \mu \mathrm{L}$. Produk transformasi ditumbuhkan dalam medium TSAA dan diinkubasi pada suhu $37^{\circ} \mathrm{C}$ semalam.

Mutan dikonfirmasi dengan menumbuhkan pada media yang disuplementasi Tryptic Soy Agar $+100 \mu \mathrm{g} / \mathrm{mL}$ Ampisilin (TSAA, OXOID), diinkubasi pada suhu $37^{\circ} \mathrm{C}$ selama 24 jam dan diamati dibawah sinar UV (Desaga Heidelberg Min UVIS). Koloni fluoresens yang tumbuh pada permukaan TSAA disuspensikan dengan pengencer BPW $15 \mathrm{~mL}$, dan dimasukkan ke dalam tabung sentrifuse $15 \mathrm{~mL}$. Untuk memisahkan pelet sel, dilakukan sentrifugasi suspensi sel $3500 \mathrm{rpm}(2.600 \times \mathrm{g})$ (HERMLE Z383K) selama 10 menit pada suhu $4^{\circ} \mathrm{C}$. Dilakukan pencucian dengan $10 \mathrm{~mL}$ BPW dan disentrifugasi kembali. Pelet sel diresuspensi dalam BPW, distandarisasi konsentrasi sel mutan dengan mengukur Optical Density dengan spektrofotometer (Shimadzu UV-2450) pada $590 \mathrm{~nm}$ sampai mencapai absorbansi 0.4. Selanjutnya, suspensi mutan ini digunakan sebagai inokulum.

\section{Penghitungan jumlah inokulum dan kestabilan mutan}

Jumlah sel inokulum dihitung menggunakan metode permukaan dengan media TSAA dan suhu inkubasi $37^{\circ} \mathrm{C}$, selama 24 jam. Penghitungan kestabilan mutan dilakukan dengan cara menumbuhkan $1 \mathrm{~mL}$ suspensi pada permukaan media Tryptic Soy Agar (TSA, OXOID) setelah dilakukan pengenceran bertingkat dengan larutan pengencer Buffer Water Phosphate (BPW, OXOID) sampai tingkat pengenceran diperkirakan 108. $10^{9} \mathrm{CFU} / \mathrm{mL}$. Inkubasi dilakukan selama 24 jam pada suhu $37^{\circ} \mathrm{C}$. Koloni dihitung dengan rumus Standard Plate Count (BAM, 2001). Kestabilan plasmid ditunjukkan dalam persen (\%) koloni fluoresens terhadap total koloni yang dihitung dengan rumus (Ma et al. 2011):

Kestabilan mutan $(\%)=$ Jumlah koloni fluoresens $(\log ) \times 100 \%$ Total koloni (log)

\section{Inokulasi dan pengeringan jagung}

Suspensi inokulum terstandarisasi dikontaminasikan ke dalam jagung sebanyak $10 \mathrm{~mL}$ untuk $300 \mathrm{~g}$ jagung setiap perlakuan suhu yang dibuat dalam 2 tabung gelas masing-masing $150 \mathrm{~g}$. Jagung dipanen pada umur tanam 90 hari untuk buah pertama (digunakan untuk ulangan 1) dan 100 hari untuk buah kedua (digunakan untuk ulangan 2). Umur panen ini dilakukan pada saat kadar air jagung mencapai 33-35\%. Jagung dikupas kelobotnya, dipilih yang diameternya seragam $(4 \mathrm{~cm})$, kemudian dipotong dengan panjang $15 \mathrm{~cm}$ (berat $\pm 150 \mathrm{~g}$ ).
Inkubasi dilakukan dalam wadah tabung gelas silinder bertutup kertas saring. Jagung terinokulasi dikeringkan dengan inkubator pada 3 suhu pengeringan $\left(40,45\right.$ dan $\left.50^{\circ} \mathrm{C}\right)$ selama 4 , 6 dan 8 hari untuk masing-masing suhu pengeringan. Dilakukan 2 kali ulangan untuk setiap perlakuan suhu. Digunakan juga jagung yang tidak diinokulasi pada setiap perlakuan suhu sebagai kontrol.

\section{Analisis kadar air, $a_{w}$ dan total mikroba alamiah selama pengeringan jagung}

Analisis kadar air, aw dan total mikroba alamiah (flora normal) dilakukan pada kelompok kontrol. Kadar air jagung dianalisis dengan metode oven pada suhu $105^{\circ} \mathrm{C}$ selama minimal 6 jam. aw diukur selama pengeringan pada suhu $50^{\circ} \mathrm{C}$ dengan menggunakan alat $a_{w}$-meter (Ro-Tronic). Total mikroba alamiah dianalisis dengan menggunakan metode tuang dalam media Plate Count Agar (PCA, OXOID) dengan jumlah sampel yang digunakan sebanyak $10 \mathrm{~g}$ dan dibuat pengenceran bertingkat (dalam BPW) sampai diperkirakan jumlah koloni $10^{5}$ $\mathrm{CFU} / \mathrm{mL}$. Diinkubasi selama $24-48$ jam pada suhu $35^{\circ} \mathrm{C}$ dan jumlah koloni dihitung dengan rumus Standard Plate Count (BAM, 2001). Analisis mikroba alamiah yang tahan terhadap ampisilin dilakukan dengan metode yang sama, tetapi menggunakan media pemupukan TSA yang disuplementasi 100 $\mu \mathrm{g} / \mathrm{mL}$ ampisilin (TSAA, OXOID).

\section{Perhitungan jumlah C. sakazakii di permukaan dan di bagian dalam jagung}

Perhitungan jumlah $C$. sakazakii yang tumbuh pada bagian permukaan jagung dilakukan dengan membilas $10 \mathrm{~g}$ biji jagung dalam $90 \mathrm{~mL}$ BPW. Perhitungan jumlah C. sakazakii pada bagian dalam jagung dilakukan dengan menggunakan biji jagung yang telah dibilas tersebut, kemudian direndam dalam larutan chloramphenicol 100 ppm dengan waktu kontak yang bervariasi (1-4 jam) sesuai dengan perkiraan jumlahnya di permukaan dan dihancurkan dengan menggunakan stomacher selama 1 menit. Masing-masing dibuat serial pengenceran yang sesuai dan dipupuk dalam media TSAA menggunakan metode permukaan. Diinkubasi 24 jam pada suhu $37^{\circ} \mathrm{C}$, koloni dihitung di bawah sinar UV. Koloni bakteri dihitung adalah koloni yang fluoresens dengan rumus Standard Plate Count (BAM, 2001) dan dikonversi dalam satuan log. Kurva reduksi C. sakazakii selama pengeringan dibuat dengan memplot jumlah koloni (log) permukaan jagung pada sumbu $Y$ dan interval waktu (hari) pada sumbu $X$.

\section{Kurva ketahanan C. sakazakii selama pengeringan jagung}

Kurva ketahanan hidup kedua isolat dibuat dengan memplotkan logaritma perbandingan jumlah koloni yang bertahan hidup pada waktu tertentu $\left(\mathrm{N}_{\mathrm{t}}\right)$ dengan jumlah koloni awal $\left(\mathrm{N}_{0}\right)$ pada sumbu $Y$, dan interval waktu (hari) pengeringan pada sumbu X. Laju penurunan jumlah (log/hari) selama pengeringan, ditunjukkan oleh besarnya slope dari persamaan linier.

\section{Pengamatan kolonisasi dan penetrasi dengan mikroskop fluoresens dan SEM}

Pengamatan kolonisasi secara mikroskopis dilakukan dengan mengamati potongan tipis kulit epidermis perikarp, kulit 
ari tip cap, dan potongan bagian dalam biji jagung yang luka dengan menggunakan mikroskop fluoresens (Olympus $\mathrm{CH} 3 \mathrm{O}$ ) pada panjang gelombang $395 \mathrm{~nm}$ dan emisi $509 \mathrm{~nm}$. Koloni mutan akan menunjukkan warna hijau berfluoresens. Pengamatan juga dilakukan dengan menggunakan mikroskop scanning electron microscopy (SEM ZEISS EVO 50) setelah sampel pada bagian tersebut dilapisi oleh emas (JAPAN Ion Coatter).

\section{HASIL DAN PEMBAHASAN}

\section{Karakteristik mutan C. sakazakii dan kestabilan mutan}

Isolat C. sakazakii YRt2a asal susu formula dan FWHd16 asal lada bubuk mempunyai karakteristik toksisitas yang berbeda yang telah diuji aktivitas sitotoksiknya secara invitro pada sel Vero. Isolat YRt2a merupakan isolat nontoksik, sedangkan FWHd16 merupakan isolat toksik (Nurjanah et al. 2013). Mutan dari kedua isolat tersebut, diperoleh melalui penyisipan plasmid GFPuv dengan proses transformasi dan tetap stabil setelah disimpan beku dan dilakukan subkultur. Proses transformasi yang dilakukan diawali dengan pembuatan sel kompeten menggunakan kalsium klorida dan diikuti dengan perlakuan heat shock (Nurjanah et al. 2012).

Plasmid GFPuv yang digunakan didisain oleh Laboratorium Clontech USA dengan karakteristik plasmid berukuran $3.3 \mathrm{~kb}$, mengandung gen yang menyandikan Green Fluorescent Protein dari ubur-ubur (Aequorea victoria) yang telah dioptimalkan untuk menghasilkan intensitas fluoresensi yang lebih tinggi ketika tereksitasi oleh sinar ultraviolet. Sekuens penyandi gen ini berada pada daerah Multiple Cloning Site (5'MCS- 3'MCS), dengan kodon inisiasi lacZ sehingga protein gabungan $\beta$ galactosidase-GFPuv dapat diekpresikan dari lac-promoter secara konstitutif. Plasmid ini juga mempunyai titik ori, sehingga dapat melakukan replikasi secara mandiri. Selain itu, mengandung gen resisten ampisilin $(A m p r)$, yang menyandikan protein $\beta$-lactamase yang dapat mendegradasi antibiotik ampisilin sehingga memiliki sifat resisten terhadap ampisilin (Gambar 1) (Clontech, 2012).

Isolat mutan YRt2a dan FWHd16 dikonfirmasi dengan menumbuhkannya pada medium TSAA dan menunjukkan koloni hijau fluoresens. Isolat mutan yang diinokulasikan perlu diketahui kestabilannya, karena plasmid yang disisipkan tidak selalu stabil dalam inangnya. Ketidakstabilan mutan dapat terjadi karena proses segregasi pada saat pembelahan sel lebih cepat dibandingkan dengan proses propagasi plasmid, sehingga plasmid tidak terdapat pada sel yang baru (Ma et al. 2011). Mutan YRt2a dan FWHd16 menunjukkan rata-rata kestabilan mutan yang cukup tinggi, yaitu masing-masing sebesar 96 dan 95\% (Tabel 2). Kedua mutan tersebut diinokulasikan pada 300 gram jagung untuk setiap perlakuan suhu. Hasil perhitungan pada media TSA menunjukkan jumlah rata-rata inokulum masing-masing isolat YRt2a dan FWHd16 adalah $2.1 \times 10^{8}(8.3 \mathrm{log}) \mathrm{CFU} / \mathrm{mL}$ dan $1.2 \times 10^{8}(8.1 \mathrm{log})$ CFU/mL (Tabel 2).

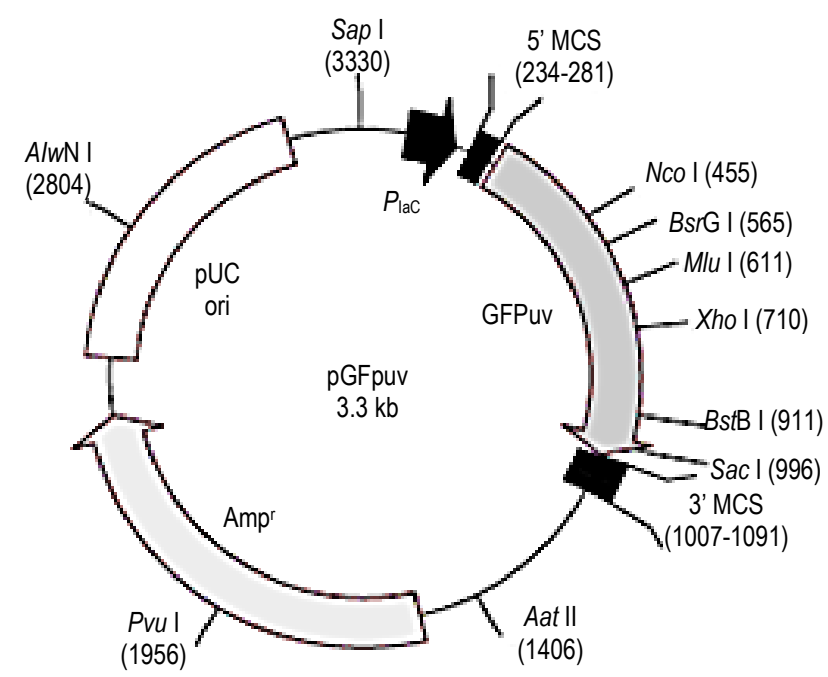

Gambar 1. Peta plasmid pGFPuv (Clontech, 2012)

Tabel 2. Profil mikrobiologi pada jagung dan inokulum

\begin{tabular}{ccc}
\hline Jagung & Total mikroba (log CFU/g) & $5.2 \pm 0.4$ \\
& Total mikroba resisten & $3.9 \pm 0.04$ \\
& ampisilin (log CFU/g) & \\
\hline Inokulum mutan & Jumlah mutan (CFU/mL) & $8.3 \pm 0.4$ \\
YRt2a & Kestabilan mutan (\%) & $96 \pm 0$ \\
\hline Inokulum mutan & Jumlah mutan (CFU/mL) & $8.1 \pm 0.3$ \\
FWHd16 & Kestabilan mutan (\%) & $95 \pm 4.2$ \\
\hline
\end{tabular}

Nilai merupakan rata-rata \pm standar deviasi

\section{Populasi mikroba alamiah pada jagung}

Jagung varietas Pioneer 12 yang digunakan dalam penelitian ini umum digunakan sebagai bahan baku pembuatan jagung pipil kering dan tepung jagung oleh industri. Pada penelitian ini jagung ini ditanam sendiri di lahan di Ciampea Bogor agar memudahkan pengamatan umur panen sesuai dengan kadar air yang diinginkan.

Jumlah rata-rata mikroba alamiah yang ada pada permukaan jagung adalah $2.0 \times 10^{5} \mathrm{CFU} / \mathrm{g}(5.2 \log \mathrm{CFU} / \mathrm{mL})$ dan terdapat mikroba yang resisten terhadap ampisilin rata-rata sebesar $4.5 \times 10^{4}$ (4.4 log CFU/mL) (Tabel 2). Adanya mikroba yang resisten ampisilin ini dapat mengganggu hasil perhitungan koloni mutan, karena mutan $C$. sakazakii dihitung dengan menggunakan media TSA yang mengandung ampisilin (TSAA, OXOID). Oleh karena itu, penggunaan media TSAA dikombinasikan dengan pengamatan di bawah sinar UV sesuai kemampuan mutan untuk berfluoresens. Hasil pengamatan di bawah sinar UV, dari semua koloni mikroba alamiah yang tahan terhadap ampisilin, tidak ada koloni yang berflouresens dengan tipikal seperti koloni mutan C. sakazakii. Penggunaan kombinasi media TSAA dan pengamatan dengan sinar UV menjadi metode penghitungan yang lebih spesifik dan mikroba alamiah dari jagung tidak akan terhitung. Hasil penelitian Sarah (2013) menunjukkan bahwa campuran kultur kapang, kamir dan BAL yang diperoleh dari fermentasi spontan perendaman jagung masih dapat tumbuh pada media TSA yang diberi $100 \mu \mathrm{g}$ Ampisilin (TSAA, OXOID). Campuran kultur tersebut terdiri dari kapang (Aspergillus flavus, A. niger, Fusarium oxysporum), khamir (Kodamaea ohmeri, Candida krusei, C. zeylanoides), BAL (Pediococcus pentosaceus, Lactobacillus plantarum, $L$. lactis, L.brevis). 
Perubahan kadar air dan populasi mikroba alamiah selama pengeringan jagung

Pengeringan jagung yang umum dilakukan oleh petani adalah dengan menggunakan panas matahari. Panas matahari suhunya berfluktuasi antara $40-54^{\circ} \mathrm{C}$ tergantung pada waktu pagi, siang atau sore hari dan kondisi cuaca. Pada penelitian ini, pengeringan dilakukan dengan 3 suhu pengeringan yaitu 40 , 45 dan $50^{\circ} \mathrm{C}$ dengan pertimbangan bahwa ketiga suhu pengeringan tersebut memberikan tekstur jagung pipil yang baik dan tidak keriput. Lama pengeringan berbeda untuk ketiga suhu tergantung kadar air yang dicapai setiap hari. Pengeringan dihentikan untuk setiap suhu setelah jagung mencapai kadar air $\leq 14 \%$. Kadar air menurun selama pengeringan pada ketiga suhu pengeringan. Semakin tinggi suhu pengeringan, penurunan kadar air semakin cepat yang ditunjukkan dengan slope persamaan linier yang semakin besar, yaitu 5.4; 3.1 dan 2.1 untuk suhu 50,45 dan $40^{\circ} \mathrm{C}$ (Gambar 2.A). Pada kadar air $14 \%$, $a_{w}$ jagung berkisar antara 0.75-0.8 (Gambar 2.B). Kadar air 14\% dan nilai aw tersebut merupakan kadar air aman untuk penyimpanan biji-bijian dimana reaksi mikrobiologis maupun kimia sangat minimal.
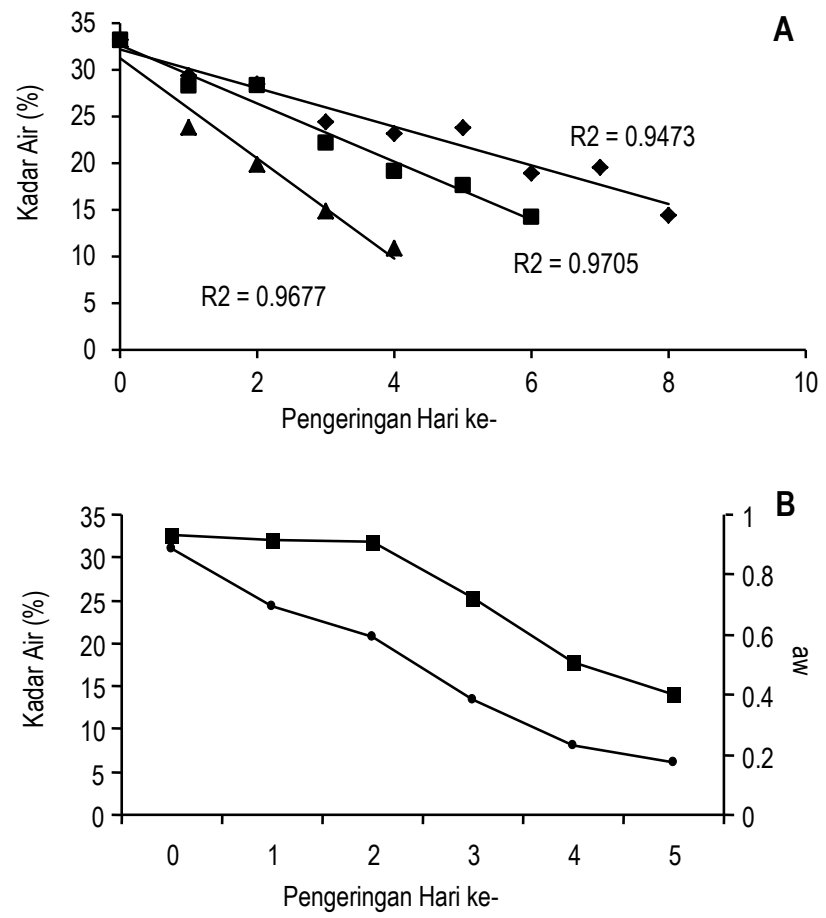

Gambar 2. (A) Grafik penurunan kadar air $40^{\circ} \mathrm{C}$; $y=-2.07 x+32$ a $45^{\circ} \mathrm{C} ; \mathrm{y}-3.12 \mathrm{x}+32 \boldsymbol{\Delta} 50^{\circ} \mathrm{C} ; \mathrm{y}=-5.36 \mathrm{x}+31$; dan (B) Grafik penurunan aw pada pengeringan suhu $50^{\circ} \mathrm{C}$; $\bullet$ kadar air; - $a_{w}$

Perubahan populasi mikroba alamiah pada jagung diamati selama pengeringan untuk mengetahui ketahanan mikroba tersebut terhadap pengeringan. Perubahan populasi mikroba alamiah ini berbeda pada ketiga suhu pengeringan. Mikroba alamiah relatif tahan terhadap pengeringan suhu $40^{\circ} \mathrm{C}$ yang ditunjukkan oleh grafik jumlah koloni yang mendatar bahkan cenderung meningkat pada akhir pengeringan. Pada pengeringan suhu $45^{\circ} \mathrm{C}$ terjadi penurunan jumlah mikroba alamiah yang lambat dan penurunan jumlah mikroba secara cepat terjadi pada pengeringan suhu $50^{\circ} \mathrm{C}$ (Gambar 3). Mikroba alamiah yang bertahan pada akhir pengeringan sebagian besar merupakan kelompok kapang.

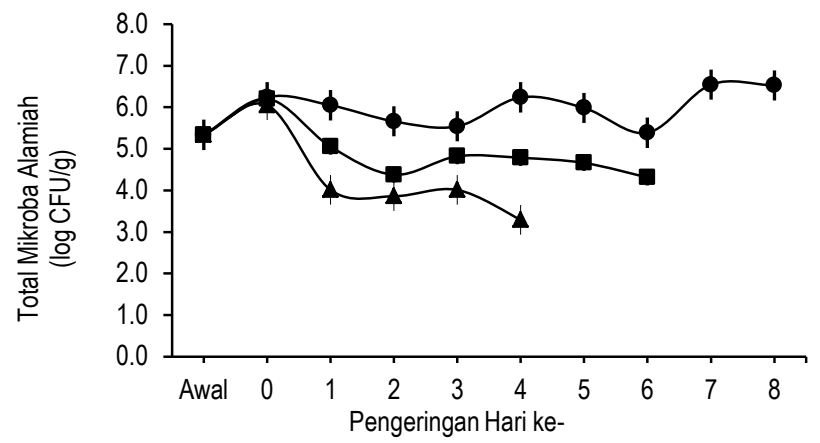

Gambar 3. Perubahan jumlah mikroba alamiah selama pengeringan jagung. suhu $40^{\circ} \mathrm{C}$. suhu $45^{\circ} \mathrm{C} \Delta$ suhu $50^{\circ} \mathrm{C}$

\section{Ketahanan hidup C. sakazakii selama pengeringan jagung}

Kedua isolat $C$. sakazakii mengalami penurunan jumlah selama pengeringan (Gambar 4). Kedua isolat tersebut masih bertahan pada proses pengeringan sebelum kadar air jagung mencapai $14 \%$. Setelah kadar air jagung mencapai $14 \%$, isolat YRt2a tidak ditemukan lagi pada akhir pengeringan, sedangkan isolat FWHd16 masih ditemukan pada ketiga suhu pengeringan walaupun jumlahnya di bawah $10 \mathrm{CFU} / \mathrm{g}$.
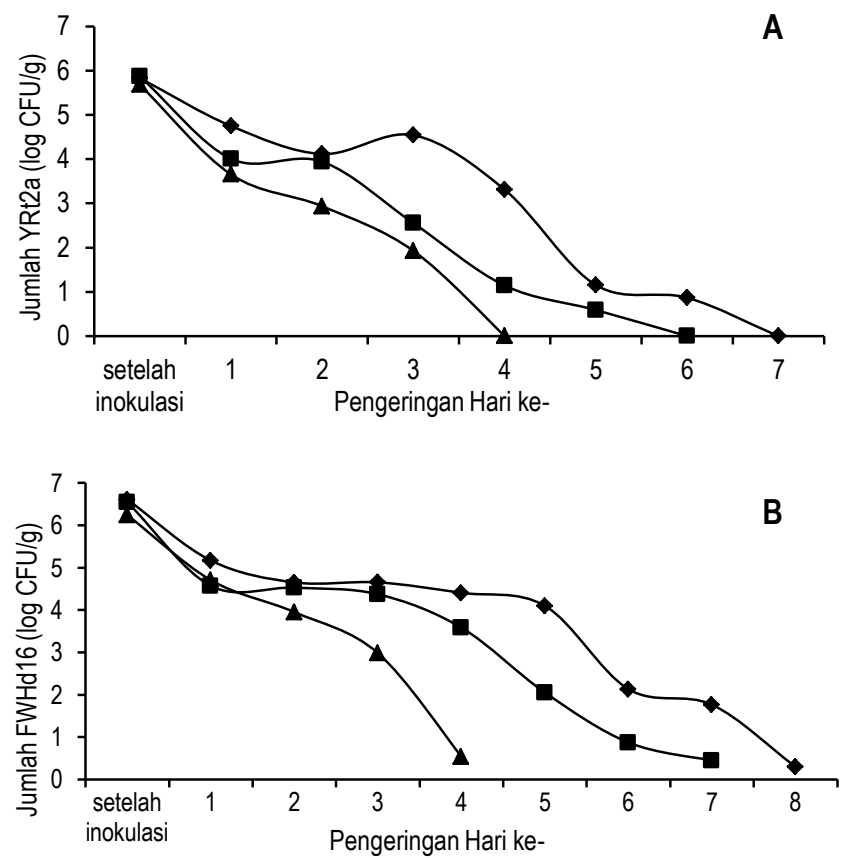

Gambar 4. Penurunan jumlah (A) C. sakazakii YRt2a dan (B) C. sakazakii FWHd16 selama pengeringan; suhu $40^{\circ} \mathrm{C}$. suhu $45^{\circ} \mathrm{C} \Delta$ suhu $50^{\circ} \mathrm{C}$

Penurunan jumlah C. sakazakii pada pengeringan suhu $40^{\circ} \mathrm{C}$ terjadi sangat lambat, yang menunjukkan bahwa suhu pengeringan tersebut tidak efektif untuk mereduksi C. sakazakii, seperti halnya tidak efektif untuk mereduksi mikroba alamiah jagung di atas. Selain karena suhu pengeringan yang terlalu rendah, penurunan jumlah yang sangat lambat tersebut ber- 
kaitan dengan penurunan kadar air yang juga lambat. Pada suhu tersebut laju penurunan kadar air hanya terjadi $2 \%$ setiap hari.

Berbeda dengan suhu $40^{\circ} \mathrm{C}$, pada suhu pengeringan 45 dan $50^{\circ} \mathrm{C}$ kedua isolat $\mathrm{C}$. sakazakii yang digunakan menunjukkan adanya penurunan jumlah yang relatif cepat selama pengeringan. Selain karena paparan suhu, penurunan viabilitas tersebut terjadi karena penurunan kadar air jagung yang cepat. Pada suhu 45 dan $50^{\circ} \mathrm{C}$, laju penurunan kadar air terjadi 3 dan $5 \%$ setiap hari. Namun demikian, suhu pengeringan $50^{\circ} \mathrm{C}$ belum efektif untuk membunuh semua C. sakazakii FWHd16 jika kontaminasi awal dalam jumlah yang tinggi. Pada jumlah awal C. sakazakii FWHd16 sebesar $10^{7} \log \mathrm{CFU} / \mathrm{mL}$, masih terdapat koloni sejumlah $10^{1} \mathrm{CFU} / g$ pada akhir pengeringan suhu tersebut.

Ketahanan hidup C. sakazakii FWHd16 dan YRt2a dapat dibandingkan dengan membandingkan laju penurunan jumlah keduanya selama pengeringan. Laju penurunan jumlah $C$. sakazakii per hari ditunjukkan oleh besarnya slope yang diperoleh dari persamaan linier kurva ketahanan. Pada ketiga suhu pengeringan, laju penurunan jumlah isolat YRt2a lebih cepat dibandingkan dengan isolat FWHd16. Hal ini ditunjukkan dengan nilai slope dari persamaan linier YRt2a yang selalu lebih tinggi dibandingkan dengan nilai slope dari persamaan linier FWHd16 (Gambar 5). Pada suhu $40^{\circ} \mathrm{C}$, laju penurunan YRt2a dan FWHd16 masing-masing sebesar 0.8 dan 0.7 siklus log/hari. Pada suhu $45^{\circ} \mathrm{C}$, laju penurunan untuk YRt2a dan FWHd16 masing-masing sebesar 1.1 dan 0.9 siklus log/hari. Pada suhu $50^{\circ} \mathrm{C}$ terjadi laju penurunan paling tinggi, untuk YRt2a dan FWHd16 masing-masing sebesar 1.3 dan 1.1 siklus log/hari.

Belum ada publikasi mengenai ketahanan C. sakazakii terhadap panas selama pengeringan jagung atau pengeringan biji-bijian lainnya. Ketahanan bakteri ini terhadap panas banyak dilaporkan dalam proses spray drying susu formula (Arku et al. 2008, Dewanti-Hariyadi et al. 2012), dalam proses pemanasan pada menstruum susu formula (Iversen et al. 2004' , Seftiono 2012), pada media pertumbuhan (Iversen et al. 2004b) dan rekonstitusi susu formula (Meutia et al. 2009). Pada penelitian sebelumnya, suhu $40^{\circ} \mathrm{C}$ disimpulkan tidak efektif untuk mereduksi $C$. sakazakii pada proses rekonstitusi susu formula (Meutia et al. 2009).

Ketahanan bakteri terhadap panas terkait dengan paparan suhu dan lama pemanasan yang pernah diterima sebelumnya. Paparan suhu sublethal atau beberapa derajat di atas suhu optimum pertumbuhannya dapat meningkatkan ketahanan panas bakteri tersebut. Pemanasan di media TSB pada suhu $47^{\circ} \mathrm{C}$ selama 15 menit, meningkatkan ketahanan hidup $\mathrm{C}$. sakazakii terhadap pemanasan (Chang et al. 2009a), kondisi kering (Chang et al. 2009b) dan spray drying (Wan-Ling et al. 2010), tetapi ketahanan hidup ini menurun jika paparan suhu yang diterimanya lebih dari $48^{\circ} \mathrm{C}$ (Chang et al. 2009a).
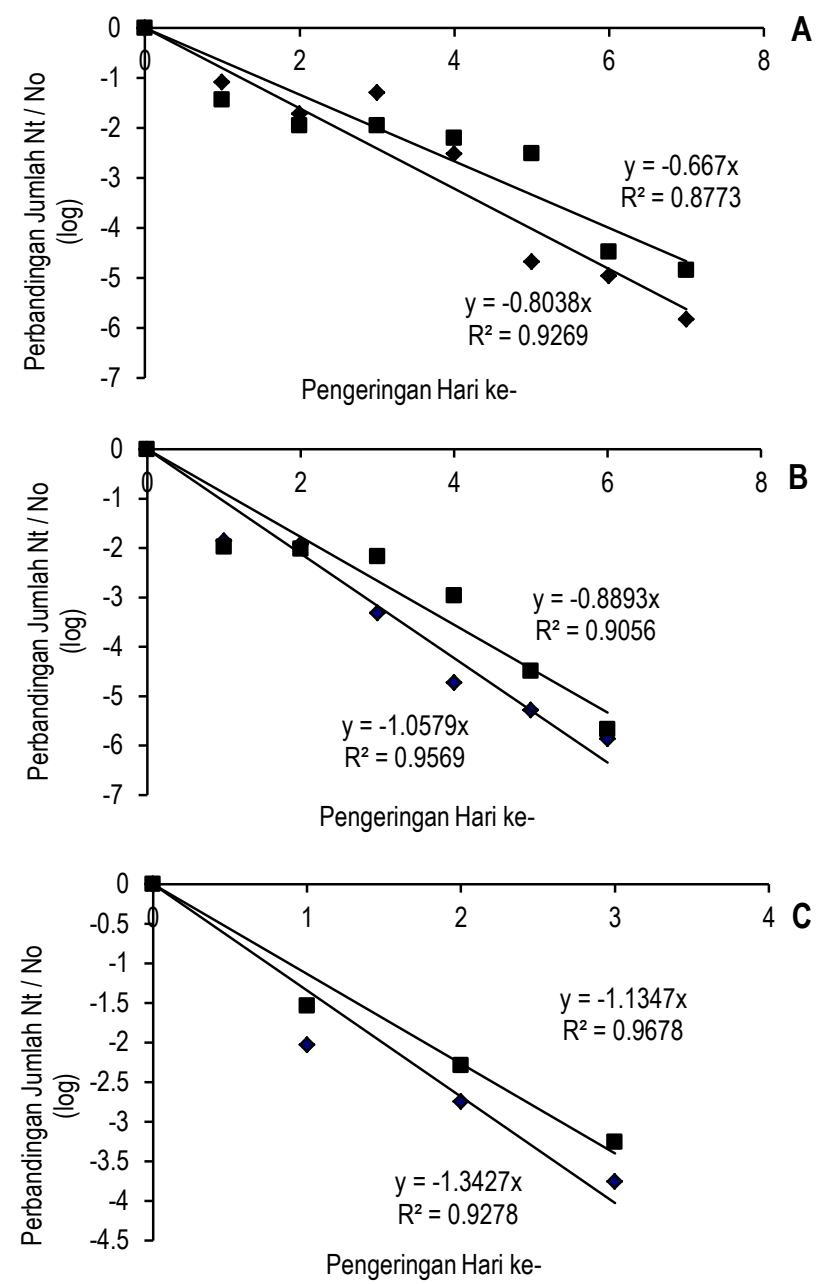

Gambar 5. Kurva ketahanan C. sakazakii pada suhu pengeringan (A) $40^{\circ} \mathrm{C}$, (B) $45^{\circ} \mathrm{C}$ dan (C) $50^{\circ} \mathrm{C}$; YRt2a — FWHd16

Isolat YRt2a merupakan isolat asal susu formula, sedangkan isolat FWHd16 berasal dari lada bubuk. Pembuatan susu formula menggunakan pengeringan semprot pada suhu yang tinggi $\left(160-170^{\circ} \mathrm{C}\right)$ tetapi dalam jangka waktu yang singkat (1-2 detik), sedangkan pembuatan lada bubuk dilakukan dengan pengeringan sinar matahari (suhu relatif rendah 35$45^{\circ} \mathrm{C}$ ) dalam jangka waktu relatif lama (3-7 hari). Dengan demikian, paparan panas yang diterima oleh FWHd16 lebih lama dibandingkan dengan YRt2a dan berada pada kisaran suhu sublethal yang masih cukup untuk mempertahankan viabilitas sel.

Jika dihubungkan dengan toksisitas kedua isolat, penurunan jumlah isolat nontoksik YRt2a lebih cepat dibandingkan dengan isolat toksik FWHd16 pada ketiga suhu pengeringan. Walaupun demikian, belum banyak laporan mengenai hubungan toksisitas dengan ketahanan panas. Kajian keterkaitan gen toksik vapBC (virulence-associated protein) pada bakteri thermofilik Sulfolobus solfataricus menunjukkan bahwa gen tersebut berperan dalam stress response terhadap panas (Cooper et al. 2009). 


\section{Kolonisasi di permukaan jagung}

Keberadaan bakteri pada produk kering juga dapat disebabkan karena kemampuan bakteri melakukan penempelan atau kolonisasi di permukaan bahan pangan. Hasil pengamatan mikroskopis dengan scanning electron microscopy (SEM) menunjukkan adanya kolonisasi isolat YRt2a dan FWHd16 pada permukaan jagung di bagian perikarp dan tip cap (Gambar 6 A dan B). C. sakazakii secara alami merupakan bakteri yang berkolonisasi pada tanaman. Bakteri ini telah ditemukan dapat berkolonisasi pada akar tanaman tomat dan akar tanaman jagung (Schmid et al. 2009) dan juga sebagai mikroba endofitik dari kedelai (Kuklinsky-Sobral et al. 2004). Kemampuan kolonisasi disebabkan karena adanya komponen heteropolisakarida pada permukaan sel bakteri yang disebut EPS (extracelluler polymeric substances) yang dapat membentuk lapisan baik pada permukaan abiotik maupun biotik (Jung et al. 2013).

Setelah dua hari pengeringan, kolonisasi isolat FWHd16 masih dapat diamati dengan mikroskop fluoresens pada suhu pengeringan 40,45 maupun $50^{\circ} \mathrm{C}$ (Gambar $7 \mathrm{~A}$ dan $\mathrm{B}$ ), sedangkan kolonisasi isolat YRt2a hanya teramati pada suhu pengeringan $40^{\circ} \mathrm{C}$. Kemampuan kolonisasi ini dapat menjadi salah satu penyebab ketahanan panas isolat FWHd16 lebih tinggi dari pada isolat YRt2a. Kolonisasi isolat FWHd16 lebih mudah ditemukan pada bagian tip cap jagung dibandingkan pada bagian perikarp. Hal ini dikarenakan tip cap merupakan bagian tersembunyi yang melekat pada kernel yang tidak terpapar suhu pengeringan secara langsung.

\section{Penetrasi ke bagian dalam jagung}

Selain berada di permukaan biji jagung, kedua isolat ini juga ditemukan di bagian dalam jagung (Tabel 3). Selama pengeringan, jumlah koloni di bagian dalam jagung ini tidak menunjukkan adanya penurunan atau peningkatan yang jelas. Hal ini mengindikasikan bahwa penetrasi terjadi secara acak atau tidak merata pada setiap biji jagung dalam satu tongkol. Pada suhu $40^{\circ} \mathrm{C}, \mathrm{C}$. sakazakii di bagian dalam masih terdeteksi sampai hari ke-4 pengeringan, sedangkan pada suhu pengeringan 45 dan $50^{\circ} \mathrm{C}$ bakteri ini sudah tidak terdeteksi lagi setelah hari ke-3. Sama dengan jumlahnya di permukaan jagung, jumlah isolat FWHd16 di bagian dalam jagung cenderung ditemukan lebih banyak dibandingkan dengan isolat YRt2a.
Kedua isolat ini ditemukan pada bagian biji jagung yang luka (Gambar $7 \mathrm{C}$ ), yang menunjukkan bahwa bagian yang luka menjadi salah satu titik masuk bakteri ini ke dalam jagung. Selain melalui bagian yang luka, penetrasi bakteri ini ke dalam biji jagung diduga terjadi melalui rongga-rongga yang terdapat di bagian ujung tip cap jagung. Hasil analisis SEM (Gambar 6 C) menunjukkan jumlah rongga ini cukup banyak pada bagian tersebut dan mempunyai ukuran cukup besar (> $10 \mu \mathrm{m}$ ) yang dapat dijadikan sebagai titik masuk untuk bakteri yang hanya berukuran 1-5 $\mu \mathrm{m}$. Dengan demikian, adanya kerusakan pada biji dan kemampuan penetrasi bakteri ini pada jagung dapat menjadi faktor adanya cemaran bakteri pada produk jagung kering.

Penelitian lain menunjukkan bahwa $C$. sakazakii dapat berpenetrasi ke dalam akar tanaman jagung dan berkolonisasi di jaringan pembuluh (Feigen, 2010), dapat berpenetrasi pada akar tanaman tomat (Schmid et al. 2009), dan menjadi penyebab busuk kuning pada bagian dalam pepaya (Keith et al. 2008). Kemampuan penetrasi ke dalam bagian tanaman melalui rongga juga ditunjukkan oleh bakteri lainnya yaitu Pseudomonas yang berpenetrasi ke bagian dalam daun melalui stomata (Spinelli et al. 2010).

Tabel 3. Jumlah koloni mutan penetrasi

\begin{tabular}{cccccc}
\hline \multirow{2}{*}{$\begin{array}{c}\text { Suhu } \\
\text { Pengeringan }\end{array}$} & Ulangan & \multicolumn{5}{c}{$\begin{array}{c}\text { Jumlah Koloni pada Pengeringan Hari ke- } \\
\text { (CFU/g) }\end{array}$} \\
\cline { 3 - 6 } & & 1 & 2 & 3 & 4 \\
\hline YRt2a & & & & & \\
$40^{\circ} \mathrm{C}$ & 1 & $n a^{1)}$ & 33 & 7 & 94 \\
& 2 & 16 & $0^{2}$ & 0 & 0 \\
$45^{\circ} \mathrm{C}$ & 1 & 4400 & 16 & 1 & 0 \\
& 2 & 3 & 0 & 0 & 0 \\
$50^{\circ} \mathrm{C}$ & 1 & 88 & 3 & 3 & 0 \\
& 2 & 3 & 0 & 0 & 0 \\
\hline FWHd16 & 1 & na & 110 & 410 & 150 \\
$40^{\circ} \mathrm{C}$ & 2 & 22 & na & 0 & na \\
& 1 & 4300 & 120 & 3 & 0 \\
$45^{\circ} \mathrm{C}$ & 2 & 90 & 200 & 0 & na \\
& 1 & na & na & 25 & 0 \\
$50^{\circ} \mathrm{C}$ & 2 & 21 & 50 & 12 & 0 \\
\hline
\end{tabular}

1) na : not applicable; hasil analisis tidak dapat digunakan karena kontrol negatif mengandung koloni fluoresens; ${ }^{2}$ ) 0 berarti di bawah limit deteksi

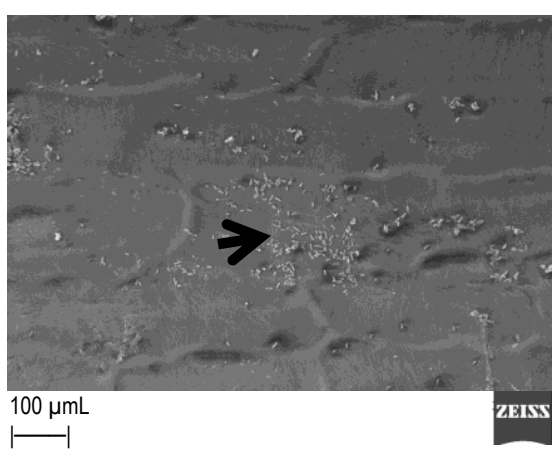

A

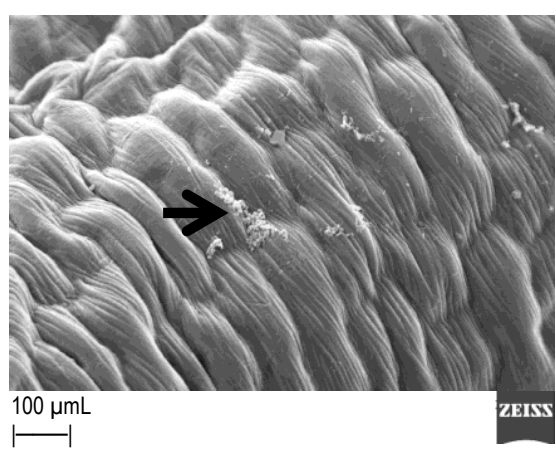

B

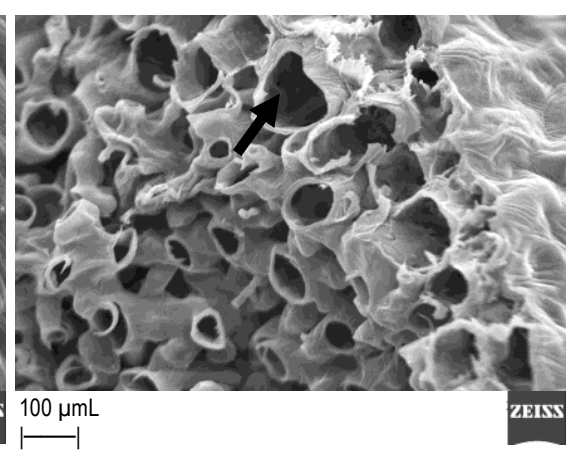

C

Gambar 6. Pengamatan SEM (500x), (A) Kolonisasi C. sakazakii pada permukaan pericarp jagung (B) Kolonisasi C. sakazakii pada permukaan tip cap jagung, (C) Rongga pada bagian tip cap jagung; 


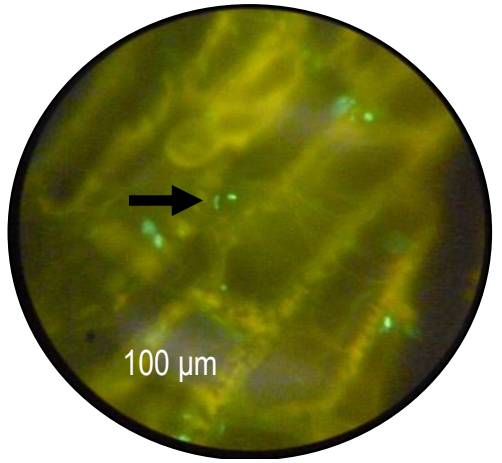

A

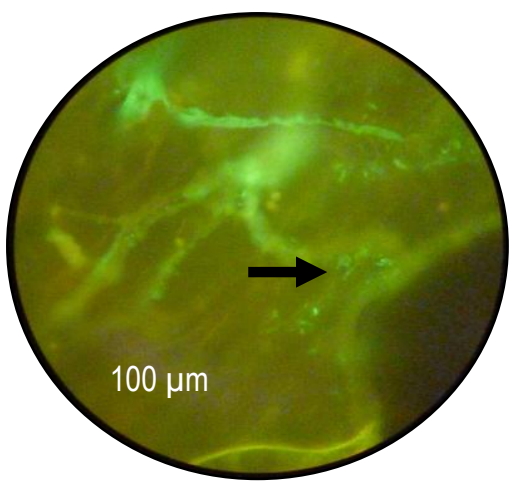

B

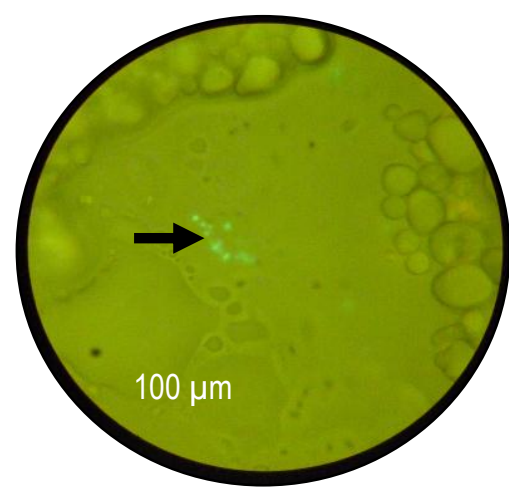

C

Gambar 7. Pengamatan mikroskop fluoresens (1000x) (A) Kolonisasi C. sakazakii pada pemukaan jagung suhu $40^{\circ} \mathrm{C}$, (B) Kolonisasi C. sakazakil pada pemukaan jagung suhu $50^{\circ} \mathrm{C},(\mathrm{C})$ Kolonisasi $\mathrm{C}$. sakazakii pada bagian yang luka

Dengan demikian faktor yang berkontribusi terhadap adanya cemaran C. sakazakii pada produk jagung kering adalah suhu pengeringan yang rendah, jumlah kontaminan awal yang tinggi dan kadar air akhir jagung yang masih tinggi. Kemampuan C. sakazakii berkolonisasi pada permukaan bahan pangan dan memasuki bahan pangan melalui luka atau rongga juga menjadi faktor pendukung terjadinya kontaminasi.

\section{KESIMPULAN}

Isolat mutan C. sakazakii YRt2a dan FWHd16 berlabel Green Fluorescent Protein dapat diaplikasikan untuk mempelajari ketahanan panas, kemampuan kolonisasi dan penetrasi bakteri tersebut selama pengeringan. Kedua isolat mengalami penurunan jumlah selama pengeringan jagung pada suhu 40 , 45 dan $50^{\circ} \mathrm{C}$ dan masih terdapat koloni sebelum kadar air jagung mencapai $14 \%$. Suhu pengeringan $40^{\circ} \mathrm{C}$ tidak efektif untuk mereduksi jumlah C. sakazakii. Isolat toksik FWHd16 lebih tahan pada ke-3 suhu pengeringan dibandingkan dengan isolat nontoksik YRt2a dengan laju penurunan untuk masingmasing suhu adalah 0.7, 0.9 dan 1.1 siklus log/hari. Kedua isolat mampu berkolonisasi di permukaan jagung dan berpenetrasi ke dalam jagung melalui bagian yang luka atau melalui rongga-rongga di bagian tip cap. Suhu pengeringan yang rendah, kadar air jagung $>14 \%$, adanya kolonisasi dan penetrasi $C$. sakazakii pada jagung dapat berkontribusi pada adanya kontaminasi bakteri tersebut pada produk jagung kering.

\section{UCAPAN TERIMA KASIH}

Ucapan terima kasih disampaikan kepada Direktorat Jenderal Pendidikan Tinggi atas pendanaan penelitian ini melalui skema Hibah Kompetensi tahun 2012.

\section{DAFTAR PUSTAKA}

Arku B, Mullane N, Fox E, Fanning S, Jordan K. 2008. Enterobacter sakazakii survives spray drying. Int J Dairy Technol 61: 102-108. DOI: 10.1111/j.1471-0307.2008. 00375.x.
Arroyo C, Condon S, Pagan R. 2009. Thermobacteriogical characterization of Enterobacter sakazakii. J Food Microbiol 136: 110-118. DOI: 10.1016/j.jifoodmicro.2009.09.013.

[BAM] Bacteriological Analytical Manual. 2001. Chapter 3: aerobic plate count. http://www.cfsan.fda.gov/. [26 Mei 2010].

Bowen AB, Braden CR. 2006. Invasive Enterobacter sakazakii diseases in infants. Emerg Infect Dis 12: 1185-1189. DOI: 1 0.3201/eid1208.051509.

[BSN] Badan Standardisasi Nasional. 2009. SNI 7388-2009: Batas Maksimum Cemaran Mikroba dalam Pangan.

[CAC] Codex Alimentarius Commission. 2008. Code of Hygienic Practice for Powdered Formulae for Infants and Young Children. Cac/Rcp 66 - 2008.

Chang $\mathrm{CH}$, Chiang ML, Chou CC. 2009a. The effect of temperature and length of heat shock treatment on the thermal tolerance and cell leakage of Cronobacter sakazakii BCRC 13988. Int J Food Microbiol 134: 184-189. DOI: 10.1016/j.ijfoodmicro.2009.06.005.

Chang $\mathrm{CH}$, Chiang ML, Chou CC. 2009b. The effect of heat shock on the response of Cronobacter sakazakii to subsequent lethal stresses. Foodborne Path Dis 7: 71-76. DOI: $10.1089 / \mathrm{fpd} .2009 .0345$.

Clontech. 2012. Certificate of Analysis pGFPuv. http://www. clontech. com [2 Februari 2012].

Cooper CR, Daugherty AJ, Tachdjian S, Blum PH, Kelly RM. 2009. Role of vapBC toxin-antitoxin loci in the thermal stress response of Sulfolobus solfataricus. Biochem Soc Trans 37: 123-126. DOI: 10.1042/BST0370123.

Crameri A, Whitehorn EA, Tate E, Willem PC, Stemmer WPC. 1996. Improved green fluorescent protein by molecular evolution using DNA shuffling. Nat Biotechnol 14: 315-319. DOI: 10.1038/nbt0396-315.

Dewanti-Hariyadi R, Gitapratiwi D, Meutia YR, Hidayat SH, Nurjanah S. 2010. Isolation of Enterobacter sakazakii (Cronobacter spp.) from Powdered Infant Formula and Other Dried Foods Obtained from Bogor Area. In: International Seminar on Current Issues and Challenges in Food Safety: science-based approach for food safety management. October 3-4, IPB International Conference Center, Bogor, Indonesia. Southeast Asian Food and 
Agricultural Science and Technology (SEAFAST) Center, Bogor, Indonesia.

Dewanti-Haryadi R, Larasati F, Nuraida L. 2012. Survival of Cronobacter sakazakii in skim milk during spray drying, storage and reconstitution. J Teknol dan Industri Pangan 13: 186-192. DOI: 10.6066/tip.2012.23.2.186.

Ehrenberg M. 2008. Scientific Background on the Nobel Prize in Chemistry: The Green Fluorescent Protein: discovery, Expression and Development. The Royal Swedish Academy of Sciences, Stockholm, Sweden. p. 1-15.

Emami CN, Mittal R. 2012. Role of neutrophils and macrophages in the pathogenesis of necrotizing enterocolitis caused by Cronobacter sakazakii. J Surg Res 172: 18-28. DOI: 10.1016/j.jss.2011.04.019.

Estuningsih S, Kress C, Hassan AA, Akineden Ö, Schneider E, Usleber E. 2006. Enterobacteriaceae in dehydrated powdered infant formula manufactured in Indonesia and Malaysia. J Food Prot 69: 3013-3017.

[FAO-WHO] Food and Agriculture Organization - World Health Organization. 2004. Enterobacter sakazakii and other microorganisms in powdered infant formula: meeting report, MRA series6. WHO, Geneva, Switzerland.

Fiegen M. 2010. Untersuchungen zum Vorkommen und zur Tenazität von Cronobacter spp. [Dissertation]. Hamburg: Universität Hamburg Fachbereich Chemie.

Gitapratiwi D, Dewanti-Hariyadi R, Hidayat SH. 2012. Genetic relatedness of Cronobacter spp. (Enterobacter sakazakii) isolated from dried food products in Indonesia. Int Food Res J 19: 1745-1749.

Hamdani FW. 2012. Evaluasi Keragaman Genetika Isolat Lokal Cronobacter spp. (Enterobacter sakazakii) yang diperoleh dari Produk Pangan Kering. [Tesis] Bogor: Fakultas Pascasarjana, Institut Pertanian Bogor.

Iversen C, Forsythe SJ. 2004a. Isolation of Enterobacter sakazakii and other Enterobacteriaceae from powdered infant formula milk and related products. Food Microbiol 21: 771-777. DOI: 10.1016/j.fm.2004.01.009.

Iversen C, Lane M, Forsythe SJ. 2004b. The growth profile, thermotolerance and biofilm formation of Enterobacter sakazakii grown in infant formula milk. Lett Appl Microbiol 38: 378-382. DOI: 10.1111/j.1472-765X.2004.01507.x.

Iversen C, Mullane N, McCardell B, Tall BD, Lehner A, Fanning S, Stephan R, Joosten H. 2008. Cronobacter gen. nov., a new genus to accommodate the biogroups of Enterobacter sakazakii, and proposal of Cronobacter sakazakii gen. nov., comb. nov., Cronobacter malonaticus sp. nov., Cronobacter turicensis sp. nov., Cronobacter muytjensii sp. nov., Cronobacter dublinensis sp. nov., Cronobacter genomospecies 1, and of three subspecies, Cronobacter dublinensis subsp. dublinensis subsp. nov., Cronobacter dublinensis subsp. lausannensis subsp. nov. and Cronobacter dublinensis subsp. lactaridi subsp. nov. Int J Syst Evol Microbiol 58: 1442-1447. DOI: 1 0.1099/ijs.0. 65577-0.

Jung JH, Choi NY, Lee SY. 2013. Biofilm formation and exopolysaccharide (EPS) production by Cronobacter sakazakii depending on environmental conditions. Food Microbiol 34: 70-80. DOI: 10.1016/j.fm.2012.11.008

Keith RC, Hilo M, Nishijima KA, Keith LM, Nishijima WT, Wall MM. 2008. Atypical internal yellowing of papaya fruit in Hawaii caused by Enterobacter sakazakii. Plant Dis 92: 487.1-487.1. DOI: 10.1094/PDIS-92-3-0487A.

Kuklinsky-Sobral J, Araújo WL, Mendes R, Geraldi IO, PizziraniKleiner AA, Azevedo JL. 2004. Isolation and characterization of soybean-associated bacteria and their potential for plant growth promotion. Environ Microbiol 6: 1244-1251 DOI: 10.1111/j.1462-2920.2004.00658.x.

Ma L, Zhang G, Doyle MP. 2011. Green Fluorescent Protein labeling of Listeria, Salmonella, and Escherichia coli 0157:H7 for safety-related studies. PLOS ONE 6: e18083. DOI: 10.1371/journal.pone.0018083.

Meutia YR, Dewanti-Hariyadi R, Estuningsih S. 2008. Characterization of 16S rRNA gene of Enterobacter sakazakii Isolated from Powdered Infant Formula. Dalam : Abstrak Seminar Nasional PATPI. 14-16 Oktober, Palembang, Indonesia. Perhimpunan Ahli Teknologi Pangan Indonesia, Jakarta, Indonesia.

Meutia YR, Dewanti-Hariyadi R, Estuningsih S. 2009. Pengaruh suhu rekonstitusi terhadap isolat lokal Enterobacter sakazakii (Cronobacter spp.) asal susu formula dan makanan bayi. Warta Industri Hasil Pertanian 26: 22-30.

Nifosi R, Tozzini V, Beltram F. 2005. Fluorescent Proteins. pp. 235-244. Dalam: Encyclopedia of Condensed Matter Physics. Bassani F, Liedl GL, Wyder P (eds). Elsevier .

Nurjanah $S$, Suhartono MT, Dewanti-Hariyadi R, Estuningsih $S$. 2012. Construction of GFPuv-labeled Cronobacter sakazakii and Cronobacter muytjensii. International Seminar of Food Factors, SEAFAST Center. Jakarta, 3-4 Oktober. SEAFAST Center, Institut Pertanian Bogor, Bogor.

Nurjanah S, Dewanti-Hariyadi R, Estuningsih S, Suhartono MT. 2013. Cytotoxic activity of food isolates Cronobacter sakazakii and Cronobacter muytjensii from Indonesia. $13^{\text {th }}$ Asean Food Conference 2013, Meeting Future Food Demands: Security and Sustainability. Singapore, 9-11 September. Singapore Institute of Food Science and Technology, Singapore.

Penna TCV, Ishii M, Junior AP, Cholewa O. 2004. Thermal stability of recombinant green fluorescent protein (GFPuv) at various $\mathrm{pH}$ values. Appl Biochem Biotech 114: 469-483. DOI: 10.1385/ABAB:114:1-3:469.

Rahmawati, Dewanti-Hariyadi R, Hariyadi P, Fardiaz D, Richana N. 2013. Isolation and identification of microorganisms during spontaneous fermentation of maize. J Teknol dan Industri Pangan 24: 33-39. DOI: 10.6066/jiti.2013.24.1.33.

Restaino L, Frampton EW, Lionberg WC, Becker RJ. 2006. A chromogenic plating medium for the isolation and identification of Enterobacter sakazakii from foods, food ingredients, and environmental sources. J Food Prot 69: 315-322.

Sarah TS. 2013. Kajian Pembuatan Maizena dari Jagung Kuning dan Sintas Mutan Cronobacter spp. selama 
Pembuatan Maizena. [Skripsi]. Fakultas Teknologi Pertanian. Institut Pertanian Bogor. Bogor.

Schmid M, Iversen C, Gontia I, Stephan R, Hofmann A, Hartmann A, Jha B, Eberl L, Riedel K, Lehner A. 2009. Evidence for a plant-associated natural habitat for Cronobacter spp. Res Microbiol 160: 608-614. DOI: 10.1016/j.resmic.2009.08.013.

Seftiono H. 2012. Ketahanan Panas Cronobacter spp. (Enterobacter sakazakii) dalam Susu Formula dan Sistem Buffer dengan Berbagai aw dan pH. [Tesis]. Fakultas Teknologi Pertanian. Bogor : Institut Pertanian Bogor.

Shimomura 0. 2005. The discovery of aequorin and green fluorescent protein. J Microscopy 217: 3-15. DOI: 10.1111/j. 0022-2720.2005.01441.x.

Spinelli F, Donati I, Vanneste JL, Costa M, Costa G. 2010. Real Time Monitoring of the Interaction Between $P$. syringae pv.
Actinidiae and Actinidia species. In: VII International Symposium on Kiwifruit/ Acta Horticulturae 913. September 12-17, Faenza, Italy. International Society for Horticultural Science, Brussels, Belgium.

Vialette M, Jandos-Rudnik AM, Guyard C, Legeay O, Pinon A, Lange M. 2004. Validating the use of green fluorescentmarked Escherichia coli 0157:H7 for assessing the organism behaviour in foods. J Appl Microbiol 96: 10971104. DOI: 10.1111/j.1365-2672.2004.02245.x.

Wan-Ling H, Chang CH, Chou CC. 2010. Heat shock effects on the viability of Cronobacter sakazakii during the dehydration, fermentation, and storage of lactic cultured milk products. Food Microbiol 27: 280-285. DOI: 10.1016/j.fm.2009.10.011. 